\title{
Seasonal changes in carbohydrate metabolism and its relationship with summer mortality of Pacific oyster Crassostrea gigas (Thunberg) in Marennes-Oléron bay (France)
}

\author{
Soletchnik Patrick ${ }^{\mathrm{a}^{*}}$, Nicole Faury ${ }^{\mathrm{b}}$ and Philippe Goulletquer ${ }^{\mathrm{b}}$ \\ aIFREMER, Laboratoire Environnement et Ressources des Pertuis Charentais (LERPC), 17390 La Tremblade, \\ France \\ ${ }^{\mathrm{b}}$ IFREMER, Laboratoire de Génétique et Pathologie (LGP), 17390 La Tremblade, France \\ *: Corresponding author : Tel.: +33 5463676 11. patrick.soletchnik@ifremer.fr
}

\begin{abstract}
This paper investigates the biological responses of Crassostrea gigas under traditional culture conditions on a mudflat in Marennes-Oléron bay. Summer mortality has been regularly observed in recent years in oysters reared using "on bottom" culture conditions. The present study attempts to provide a better understanding of the mortality phenomenon through biological parameters. Classical 'field parameters' such as mortality and growth rates, and quality index (dry meat weight / dry shell weight $\times 1000$ ) were monitored. Additional parameters, as biochemical composition of oyster meat and glucose incorporation capacity, were included as potential new bioindicators. The work highlighted a critical timing (May-June) preceding the summer mortality and characterised by an arrest in lipid synthesis and a decrease in carbohydrate content. During this period, growth (especially gonad maturation) either slowed down significantly or even stopped. The first mortality event occurred during a growth renewal period at the end of June. Short-term analysis (15 days) provided information to identify such responses which may indicate a physiological stress and demonstrating the need for further investigation. The seasonal food availability (estimated from chlorophyll a levels) did not facilitate the mortality understanding which occurred after water temperature went above $18-19{ }^{\circ} \mathrm{C}$. Nevertheless, this study shows carbohydrate anabolism contributed in the physiological stress leading to mortality events.
\end{abstract}

Keywords: Crassostrea gigas; Summer mortality; Maturation; Glycogen incorporation; In vivo; Glycogenolysis; Marennes-Oléron bay 


\section{Introduction}

Oysters harvested from public fisheries have been consumed throughout the world for millennia, gradually becoming a product of "traditional" aquaculture, as in Japan where oyster-farming has been practised for more than 1,000 years (Farley, 1992). In Europe, the Pacific cupped oyster Crassostrea gigas was introduced from Japan and Canada (British Columbia) during the early 1970s to replace the ailing Crassostrea angulata, and became the main oyster species produced in European waters (Grizel, 1996; Goulletquer and Héral, 1997). Meanwhile, this species has become the leading aquaculture product at the worldwide level (FAO, 2004).

Since the beginning of the 1960s, 'abnormal' episodes of $C$. gigas oyster mortality (mortality rate $>30 \%$ of the population) have increased throughout the world (Mackin, 1961; Imai et al., 1965; Sinderman, 1976; Beattie et al., 1980; Perdue, 1983; Farley, 1992). Oyster production in Japan and the West Coast of the United States was particularly affected in the 1960s and 1970s by summer mortality events that destroyed up to $60 \%$ of $C$ gigas livestock (Glude, 1975; Koganazawa, 1975. 'Abnormal' mortality episodes have also occurred in recent years (Goulletquer et al., 1998; Cheney et al., 2000). While some mortality events are clearly of pathogenic origin (Beattie et al., 1980; Farley, 1992; Renault et al., 1995), others occurred during exceptional climatic conditions (Mackin, 1961). In contrast, the specific causes and physiological pathways behind summer mortality events have until now remained unspecified.

In France, where $\underline{C \text {. gigas }}$ has been cultivated since the early 1970s, significant mortality (> $30 \%$ occurred in 1976-77 (Parache, 1989) and then in the 1980s and 1990s at various oyster-rearing sites: (1) Arcachon bay on the south-west coast of France (Maurer et al., 1986) in 1982-83; (2) Marennes-Oléron bay in 1988 and 1993; (3) rearing sites in Brittany and Normandy in 1994-95 (Goulletquer et al., 1998). In Marennes-Oléron bay, oysters reared using the traditional "on bottom" culture and deployed directly on the mud show higher mortality rates than oysters reared in plastic bags deployed off-bottom on iron tables (Soletchnik et al., 1999, Soletchnik et al., 2005). Oyster summer mortality commonly occurs during the maturation period (Mori, 1979; Perdue et al., 1981; Maurer and Borel, 1986). Mori et al. (1965) and Tamate et al. (1965) compared Onagawa and Matsushima bays where low-level and highly significant summer mortality occurred respectively. They concluded that the main cause of summer mortality, in eutrophic Matsushima bay, was over-maturation of oocytes with "physiological disorder and metabolic disturbance".

A comprehensive research program, called MOREST, has been developed recently in France to address the 'Summer C. gigas oyster mortality' syndrome, specifically focusing on the interactions between pathogens-host and environment. Among the various tasks, in-situ characteristics of abnormal oyster mortality events are critical to develop further experimental works at the laboratory level.

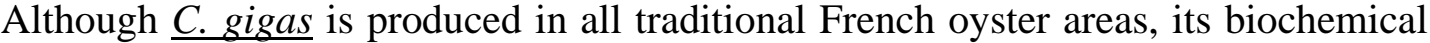
cycle has been well described mainly without mortality event, and only in Arcachon Bay (Maurer and Borel, 1986), Marennes Oléron Bay (Deslous-Paoli and Héral, 1988) and Normandy (Heude-Berthelin et al., 2001). These authors showed the increase of lipids and concomitant reduction of carbohydrate during the vitellogenesis process (Arcachon and Marennes Oléron Bays), when carbohydrate remained at a higher level in Normandy. The biochemical cycle in bivalves shows glycogen storage activity during favourable trophic conditions, followed by 
mobilisation and conversion of these reserves during the maturation period (reviewed by Martin, 1966 and Walne, 1970 in Gabbott, 1975). This cycle was confirmed in the Pacific oyster C. gigas (Mann 1979; Perdue et al., 1981; Deslous Paoli and Héral, 1988), with a late utilisation of glycogen (ripe stage) compared to the mussel Mytilus

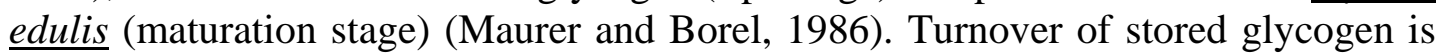
correlated with the annual reproductive cycle and food availability (Gabbott, 1975; Ruiz et al., 1992; Mathieu and Lubet, 1993). Glycogen metabolism pathways are controlled by glycogen synthetase, hemolymph glucose concentration and feeding conditions (Gabbott and Whittle, 1986). Gabbott (1975) suggested that vitellogenesis takes place at the expense of stored glycogen reserves in the blue mussel Mytilus edulis.

Glucose incorporation into glycogen was first studied in the flat oyster Ostrea edulis by Fando et al. (1972), who reported that gill or mantle tissues incorporated significantly more glucose than muscle tissue by a factor of 5. Lenoir et al. (1989) focused on vesiculosis cells of the labial palps in the blue mussel (Mytilus edulis). Berthelin et al. $\left(2000^{\mathrm{a}}, 2000^{\mathrm{b}}\right)$ then adapted the glucose incorporation method to $\underline{C}$. gigas.

As low glycogen content has often been implicated in oyster mortality events during the reproduction period, a detailed examination of the relationship between bioenergetical pathways and mortality events was carried out. The use of labelled Dglucose incorporation rate was assessed as an independant bioindicator for glycogen synthesis in relation to mortality events. Actually, no relationship has been detailed until now between reproductive cycle and carbohydrate storage accumulation at the labial palp level.

Our study aims to investigate relationships between maturation and mortality by using various bio-indicators. We hypothesize that somehow, a physiological disorder, involving an unbalanced mobilization of energetic reserves at a critical stage during the maturation, might result in oyster death. We additionally examined the relationship between mortality and environmental conditions, specifically temperature and carrying capacity. Meanwhile, influence of environmental parameters (i.e., water temperature and food availability) is discussed for the specific case of traditional "on bottom" oyster culture in the southern part of the MarennesOléron bay.

\section{Material and methods}

\subsection{Experimental site and oysters}

The Marennes-Oléron bay is situated on the French Atlantic coastline at the near vicinity of the Charente river estuary. An experimental site within a 250 ha oyster bed (Ronce-Perquis) in the southern part of the sound has been used since 1996 for oyster experimental studies (Lodato, 1997; Soletchnik et al., 1999). The sediment type is a muddy-sandy bottom characterised by a $60 \%$ immersion rate. Seawater temperature was recorded every 15 minutes using an Ysi probe.

The experimental batches of cupped oysters, Crassostrea gigas were reared in Marennes-Oléron bay and consisted of two groups, A and B, which were 3.5 and 4.5 years old respectively at the beginning of experiment. Both group differ by their reproductive effort, which increases concomitantly to age (Deslous-Paoli and Héral, 
1988). Oysters were placed directly on the mudflat, a traditional cultural practice which commonly results in higher mortality rate (Soletchnik et al., 1998; Soletchnik et al, 2005). The rearing density was 400 oysters per square meter. Six individually fenced oyster grounds (1/2 square meter surface) were used per age class as replicates and for each sampling date. Oysters were reared from March 22, 2000 to January 08, 2001.

Thirty oysters were sampled on a bi-weekly basis to assess biometrics and biochemical composition. Mortality rate was estimated at the same time by systematically counting dead and live oysters within three different enclosures per age class (A and $\mathrm{B})$.

\subsection{Biological parameters}

Dry meat weight was estimated (to the nearest $0.01 \mathrm{~g}$ ) after freeze-drying for 36 hours 30 oysters per sample. Walne \& Mann index (1975) was calculated as the ratio of dry meat weight / dry shell weight $\mathrm{x} 1000$. The daily mortality rate was calculated for each sampling period: [(initial number - final number / ( final number + initial number)/2] / number of days x 100.

At each sampling date, biochemical analyses of tissues were carried out on each group of oysters in 3 replicate pools (10 oysters/pool).

Biochemical analysis were conducted on an aliquot of ground tissues of each pool. Lipids were extracted and purified according to the protocol of Bligh and Dyer (1959) with the analytical procedure from Marsh and Weinstein (1966). Carbohydrate and glycogen (precipitated with absolute ethanol) were quantified using the phenol-sulphuric acid method as described by Dubois et al. (1956). The results are expressed in mg of lipid, carbohydrate and glycogen, using a standard one gram oyster tissue weight.

Glycogen synthesis was measured on vesiculosis cells from the labial palps following the method developed by Berthelin et al. $\left(2000^{\mathrm{a}}, 2000^{\mathrm{b}}\right)$. Tissue was lightly minced and incubated in $50 \mu \mathrm{l}\left[\mathrm{U}-{ }^{14} \mathrm{C}\right]$ glucose $(0.5 \mu \mathrm{Ci})(\mathrm{ICN})$ and $50 \mu \mathrm{l}$ of unlabelled D-glucose at the final concentration of $1.5 \mathrm{mM}$. Incubation was maintained 7 hours at $15^{\circ} \mathrm{C}$, in a medium with 5 millions cells/ml, radioactivity was then determined using a 2200 CA-TRI CARB scintillator and neo-synthesis of glycogen estimated for each sampling date.

\subsection{Statistical analysis}

Student tests were applied to compare the glucose incorporation (after 7 hours incubation) to a tissue of labial palp without any incorporation of labelled glucose (control). Mean values and associated standard deviations (SD) were calculated for biometrics measurements $(n=30)$ and biochemical analysis (3 pools of 10 individuals), using the statistical analysis software STAGRAPHICS Plus ${ }^{\circledR}$. 


\section{Results}

\subsection{Mortality and growth}

No significant difference was observed between mortality rates of the different age classes (Figure 1). An initial 6-9 \% mortality event in April resulted from the acclimation phase. However, a significant mortality event reaching a 32-39 $\%$ peak occurred between July and mid-August. By the end of the experiment (10 months), mortality rate had reached $42.8 \%$ and $50.5 \%$ for $\mathrm{A}$ and $\mathrm{B}$ groups, respectively.

Seawater temperature rose from $10^{\circ} \mathrm{C}$ at end of March, up to $22^{\circ} \mathrm{C}$ in August, to decrease to $12^{\circ} \mathrm{C}$ in November. Mortality rate was reported after reaching a $19^{\circ} \mathrm{C}$ seawater temperature threshold (Figure 1).

Fig. 1. Mortality rate (\%) for oyster groups A (3.5 year old) and B (4.5 year old) in relation to the seawater temperature cycle $\left({ }^{\circ} \mathrm{C}\right)$. Arrows indicate the summer mortality period.

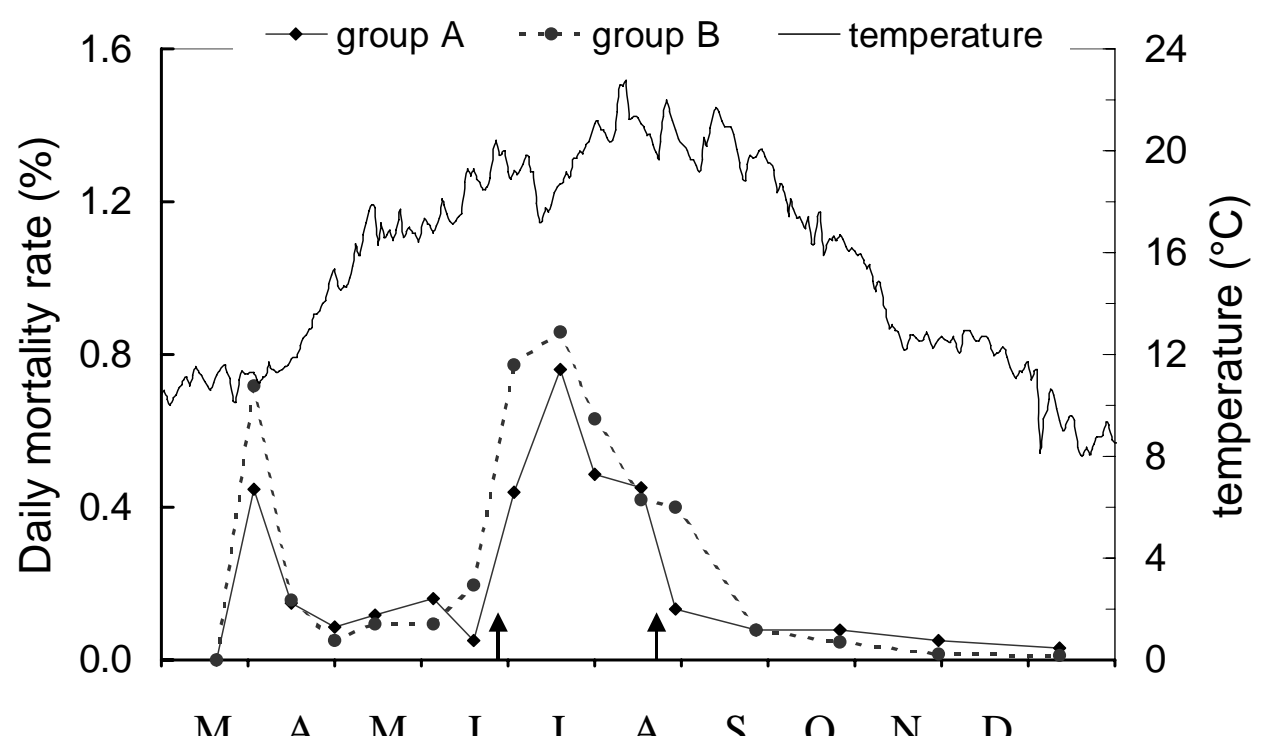

The dry meat weight increase from $0.5 \mathrm{~g}$ to $1.5 \mathrm{~g}$ (30 oysters/sample) between March and July was mainly due to gonadal development (Figure 2a). Dry meat weight then decreased to $1.0 \mathrm{~g}$ during the first fortnight of August following spawning and gamete release. Dry meat weight then decreased slightly to 0.6-0.7 $\mathrm{g}$ during the fall.

The Walne and Mann (1975) condition index (dry meat weight / dry shell weight $\mathrm{x}$ 1000) increased from 20-30 to 50\% from March to May (Figure 2b). The index value remained stable from mid-May until the third week of June. It then increased up to $70 \%$ until the beginning of August and decreased drastically following spawning. The index then decreased slightly to $20 \%$ o during the fall. 
Fig. 2. Growth (a) and Walne - Mann Index of quality (b) for oyster groups A and B. ( \pm S.D). Arrows indicate the summer mortality period.
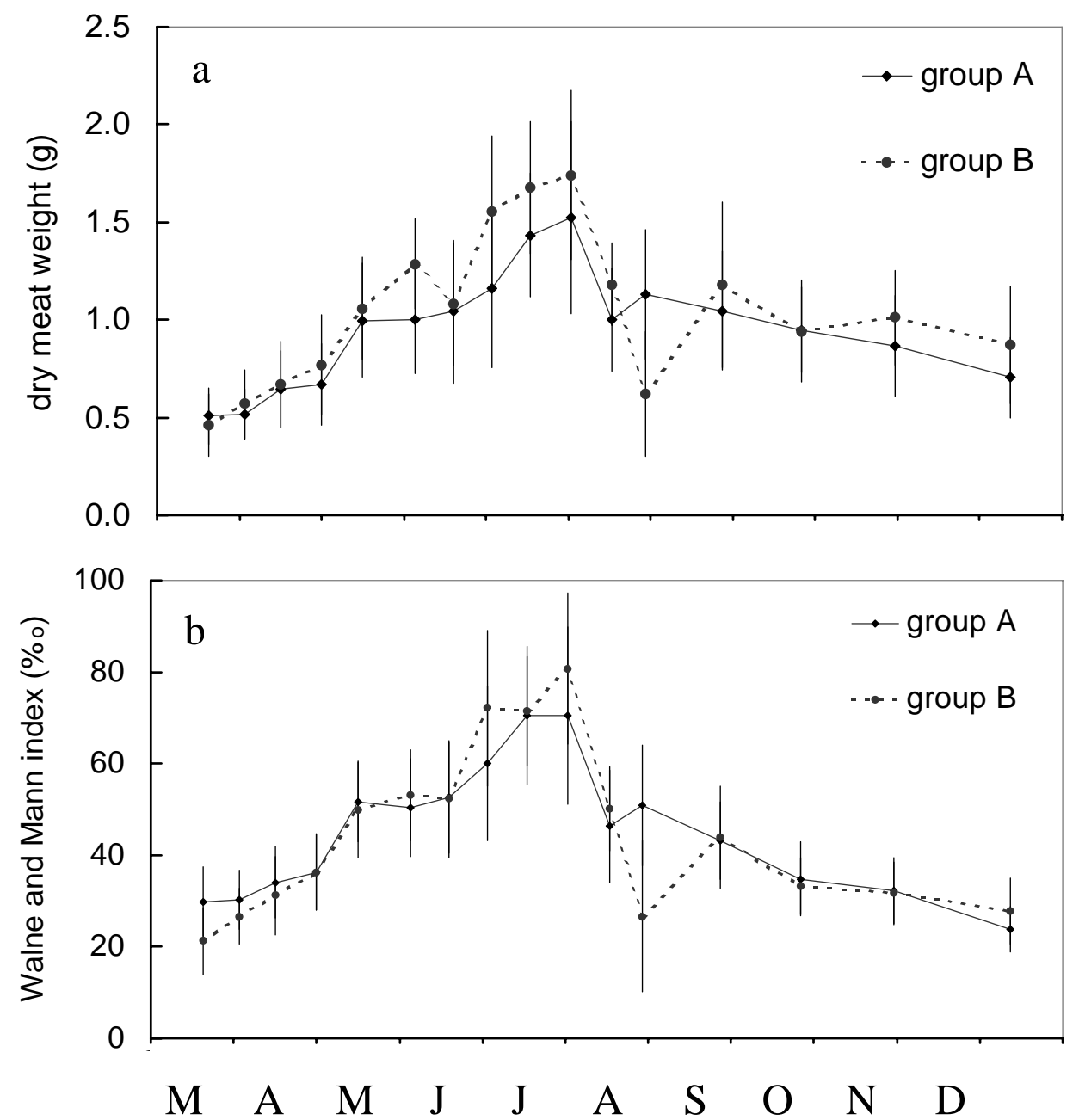

\subsection{Biochemical content}

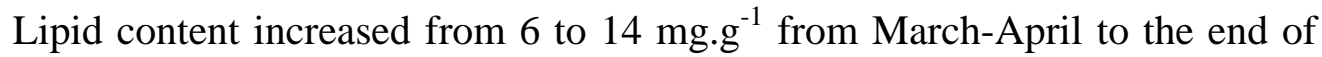
June. However, the increase of lipid concentration was stopped during the first fortnight of June at $10 \mathrm{mg} \mathrm{g}^{-1}$ (Figure 3a). Meanwhile, carbohydrates decreased from 10 to $4 \mathrm{mg} \cdot \mathrm{g}^{-1}$ and glycogen content from 8 to $2 \mathrm{mg} \cdot \mathrm{g}^{-1}$ between early spring and July (Figure 3b,c). Carbohydrates and glycogen content remained at their lowest values from mid-June to the end of July. Both components increased again up to 12-16 mg. $\mathrm{g}^{-1}$ and remained at their highest values throughout the fall. In early August, lipid content dropped down to $9 \mathrm{mg} \cdot \mathrm{g}^{-1}$ and maintained around that value during the fall (Figure 3a). Significant differences $(p<0.05)$ between groups appeared for both carbohydrate and glycogen contents in April, at the end of June, and in August, thus revealing an age class specific physiological contribution to the metabolic responses. 
Fig. 3. Proximate biochemical composition of dry oyster meat (mg. g-1 dry meat weight) over the experimental time period: Lipid (a), Carbohydrate (b) and Glycogen (c). ( \pm S.D). Arrows indicate the summer mortality period
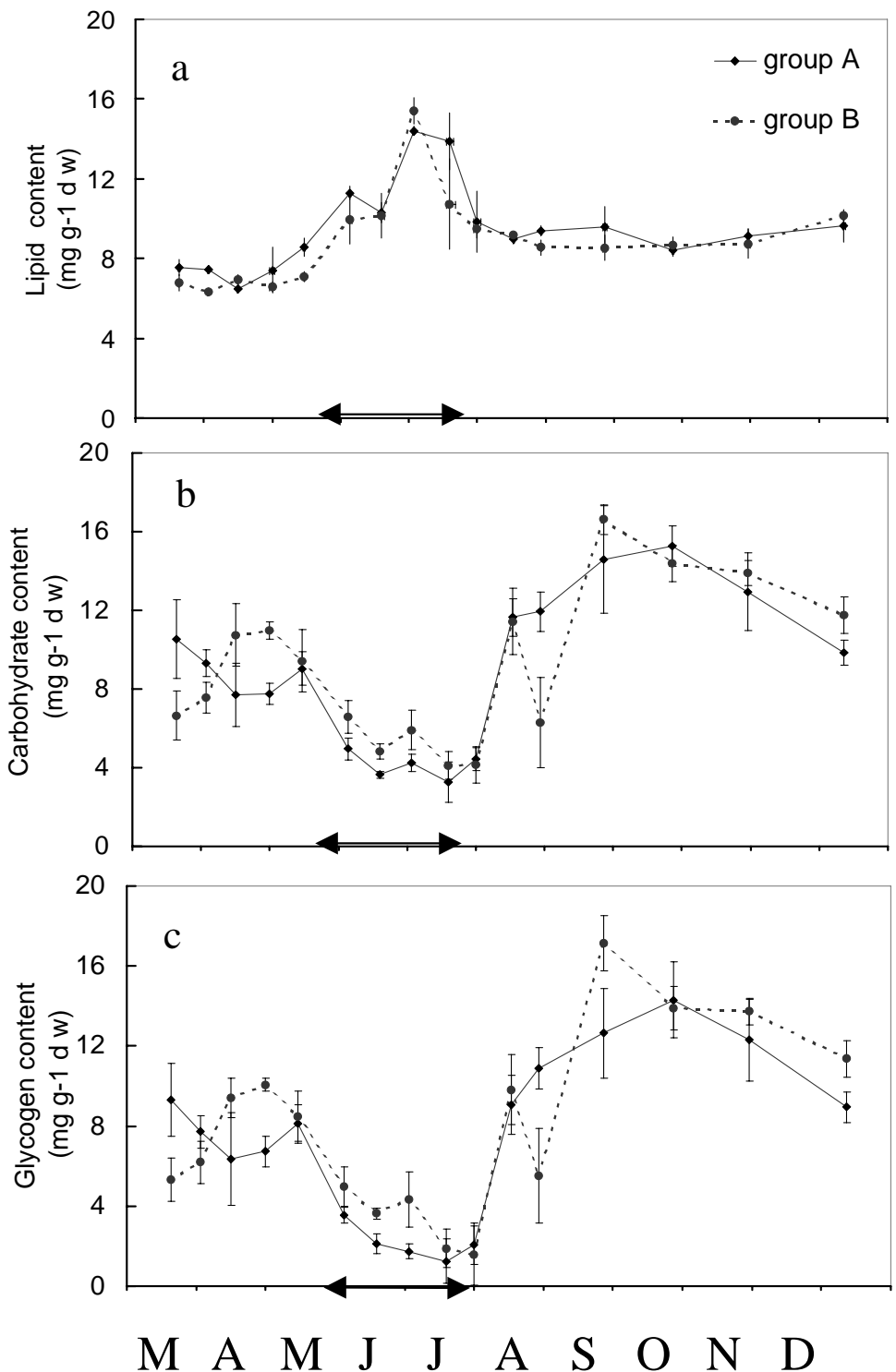

Both carbohydrates and lipid contents (mg per oyster) increased from $40 \mathrm{mg}$ to 80 mg from mid-March to mid-May (Figure 4). Lipid content increased up to 200 with a visible disruption in early June. Glycogen decreased to $30 \mathrm{mg}$ in June and remained below 40 until early August. Glycogen rose in two steps: once up to $100 \mathrm{mg}$ in August, and then to $170 \mathrm{mg}$ in early fall. A first lipid decrease from 200 to $160 \mathrm{mg}$ occurred when glycogen content reached its lowest value $(\sim 20 \mathrm{mg})$ during the second fortnight of July. The lipid content continued to fall in early August, concomitantly to the spawning. This coincided with an increase in carbohydrate content related to a growth rebound (Figure 4). Carbohydrate continued to increase 
up to $160 \mathrm{mg}$ in September, and then slightly decreased during fall, while lipid content remained around $80 \mathrm{mg}$.

Fig. 4. Mean proximate biochemical composition of the two oyster batches (A and B): Lipid, Carbohydrate and Glycogen (mg oyster-1). Arrows indicate the summer mortality period.

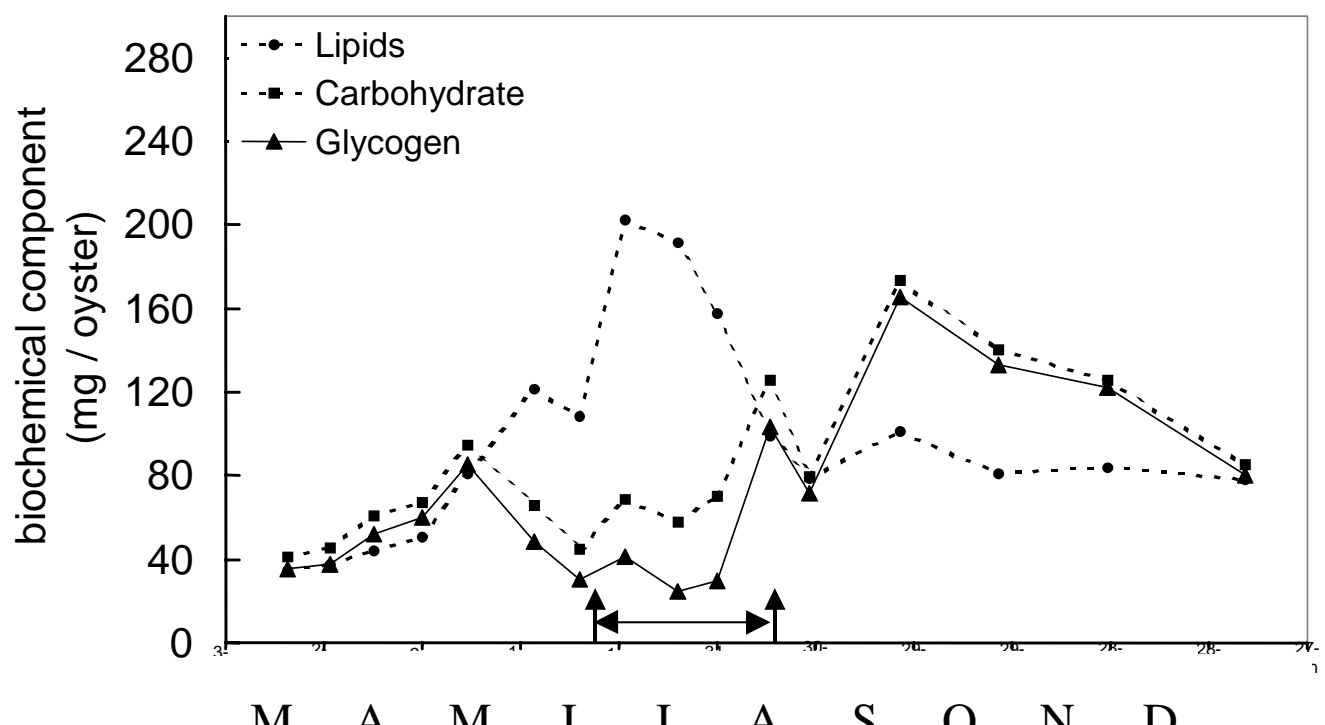

\subsection{Glucose incorporation capacity}

Glucose incorporation rates ranged from near 0 (end of March) to $1.7-1.8 \mathrm{nM}$ in mid-May (Figure 5) for both groups A and B. Significant difference $(p<0.05)$ in glucose incorporation between age classes A and B occurred in March, May and October, showing an age-specific response difference in oyster physiology. Main difference occured when glucose incorporation reached $1.7 \mathrm{nM}$ and $0.5 \mathrm{nM}$ for B and A groups respectively. 
Fig. 5. Seasonal variation of glycogen storage capacity, measured through [U-14C] incorporation into glycogen. Incubation time was 7h in an exogenous glucose concentration of $1.5 \mathrm{nM}$ and 2.5106 vesiculosis cells from oyster palps. ( \pm S.D). Arrows indicate the summer mortality period.

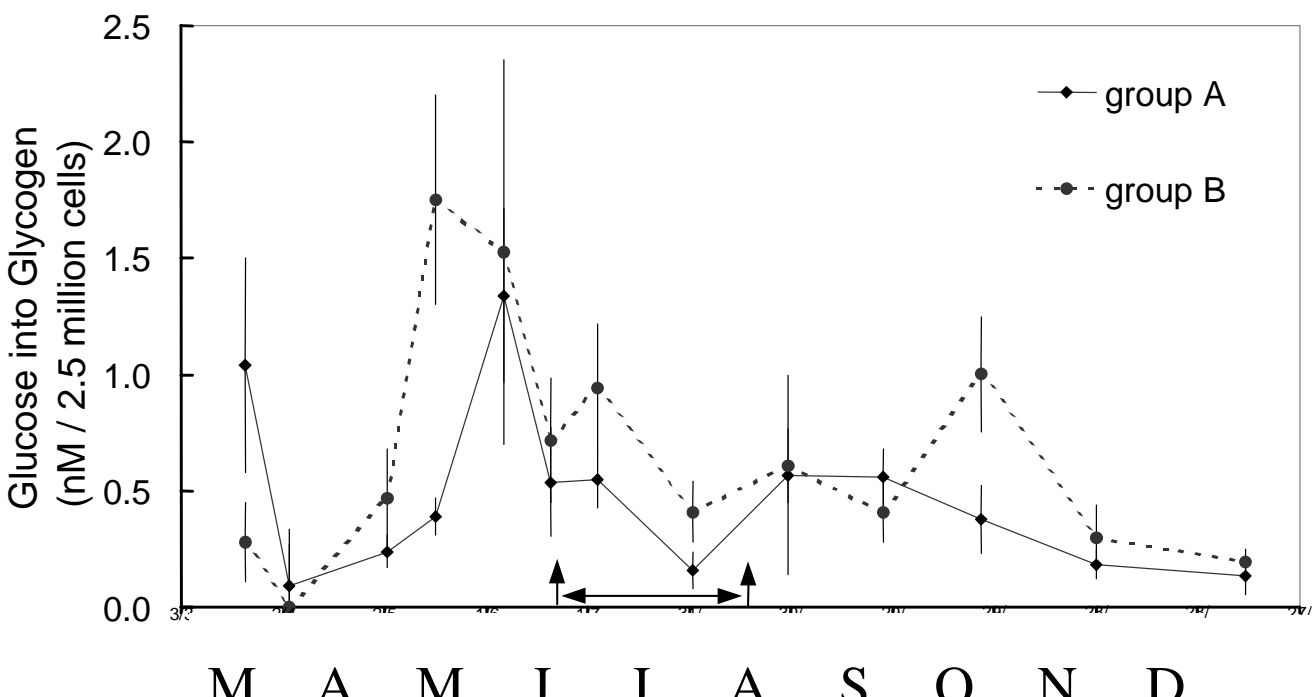

\section{Discussion}

Sexual maturation in bivalves is closely associated with the carbohydrates breakdown whatever the rearing site (Mori et al., 1966 - in Gabbott, 1975). The first drop in carbohydrates, occurring from mid-May to mid-June, is directly related to the catabolism process converting carbohydrates into lipids. During this process, the meat lipid content increases (reviewed by Gabbott, 1975, Bayne, 1976) as lipid storage in the gametes is initiated (vitellogen synthesis).

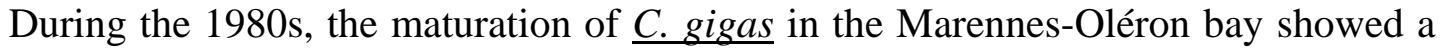
typical pattern of carbohydrate breakdown and progressive increase of the lipid content in May-June (Héral et al., 1983; Deslous-Paoli and Heral, 1988). In the present study, dry meat weight, Walne and Mann (1975) index and lipid content increase are correlated to the maturation process (Deslous-Paoli and Héral, 1988). A decrease for those parameters in May-June suggested an abnormal maturation process. Those results prompt us to hypothesize that the spring disruption in the lipid concentration increase, during the maturation process, corresponds to an abnormal physiological response of the oysters and could be correlated to mortality events. Similarly to Japanese results (Mori, 1979), histological studies carried out during oyster mortality events in 1982-83 in Arcachon bay (Maurer et al., 1986) showed digestive epithelial thinning and tubule widening, which are characteristic symptoms of lipid metabolism disorders (Mori, 1979). Although no histological analysis were carried out in the present study, lipid cycles appeared to be disturbed in May-June, when a regular increase would have been expected under normal circumstances.

Oysters reared in ecosystems showing high food seasonal variability are able to store glycogen during early spring (Maurer and Borel, 1986 ; Deslous-Paoli and Héral, 1988), in summer or early winter (Heude-Berthelin, 2000; Heude-Berthelin et al., 
2001). In our study, especially low glycogen content values indicated low energy storage for both groups of oysters in summer. Glycogen can be simultaneously an energy source for growth and stored in specific cells as energetic reserve during the vitellogenesis process (Deslous-Paoli and Héral, 1988). Carbohydrate content and especially glycogen storage can be considered as bioindicators of recent environmental status, but also reflect an oyster's capacity to sustain further environmental stress.

Deslous-Paoli and Héral (1988) recorded a low glycogen content ( 1\% of body weight) in oysters reared in the Marennes-Oléron bay in 1979-1982. They suggested overstocking and limited carrying capacity as the main causes. This situation, associated with seasonal temperature increases, may leave oysters with an energetic deficiency during physiological critical periods. A limited glycogen content has often been associated with mortality events (Mori, 1979 ; Perdue et al., 1981 ; Allen et Downing, 1986). Similarly, Maurer and Comps (1986) correlated mortality events in juvenile oysters to their lowest values of carbohydrate content $\left(1 \mathrm{mg} \cdot \mathrm{g}^{-1}\right)$. Mori (1979) linked an oyster mortality event in an eutrophic environment (Matsushima bay) to a $5-10 \%$ of tissue weight threshold in glycogen content. Mori et al. (1965) considered this low carbohydrate content and high gonad development as combined factors increasing the mortality risk. In our study, the lowest values of glycogen content were observed in late June and in July, while summer mortality started in late June during a growth rebound. Moreover, Perdue et al. (1981) demonstrated that oyster mortality consistently occurred during the storage phase of the carbohydrate cycle and after spawning events in Puget Sound. In the present study, mortality events occurred during the maturation process. Our results suggest that carbohydrate anabolism may be involved in the physiological disorder affecting the maturation process, then resulting in mortality events. Both results support the implication of carbohydrate metabolism in mortality rate and show that glycogenesis requires further study.

Previous studies have shown an inverse relationship between storage reserves and capacity for glycogen synthesis in Crassostrea virginica (Galtsoff, 1964). In winter, the glycogen-labelling capacity of the gill tissue of $\underline{C}$. virginica decreased owing to the high content of glycogen (Galtsoff, 1964). Berthelin et al. (2000a) reported that oyster glycogenesis capacity in Marennes-Oléron bay is low in spring and summer, while reaching its peak in fall. However, the present study shows that glycogenesis capacity varied over the maturation period without specific correlation with glycogen content. Actually, the oyster capacity to synthesise glycogen rose over the two last weeks of May whereas glycogen decreased drastically during the second part of June. Therefore, the capacity of glycogen synthesis is limited whereas the glycogen demand for the maturation process is high. Glucose incorporation values remained below $1.5 \mathrm{nM}$ / 2.5 millions cells in this study, but reached $4 \mathrm{nM}$ / 2.5 millions cells in December 1997 (Berthelin et al., 2000b). These authors reported that glucose incorporation remained below $1 \mathrm{nM}$ in spring, and reached its lowest values in summer. Fando et al. (1972) reported a similar pattern in Ostrea edulis, with a low glucose incorporation when glycogen concentration was high and the opposite when glycogen concentration was low in the body flesh. These results suggest that a glycogen regulator may exist, inhibiting its own synthesis according to its concentration in the oysters.

Therefore, despite the small number of experiments conducted on this aspect of bivalves metabolism, the capacity for glucose incorporation in our study appears to 
be highly variable in spring, which might be a characteristic of oyster metabolic "instability" during this period.

In the present study, glucose incorporation is highly correlated to food availability. A remarkable exception was the glucose incorporation increase up to $1.5 \mathrm{nM}$ in May without any identified algal bloom (described by chlorophyll a concentration) (Figure 6). Incorporation then dropped down before and during the mortality event. This prompts us to suggest a disorder of the glycogen metabolism. Previously, Perdue et al. (1981) hypothesised that there was a relationship between a change in

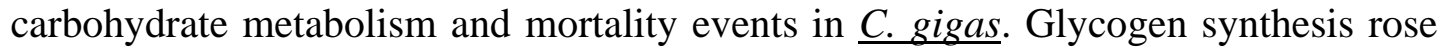
during the last two weeks of May while glycogen decreased drastically from $80 \mathrm{mg}$ to $40 \mathrm{mg}$, and then dropped during the second part of June when glycogen content was as low as $30 \mathrm{mg}$ (Figure 6). This response may reveal a disorder in glycogen metabolism during the period preceding mortality events. This mortality occurred during the two summer months when glycogen content was as low as $25 \mathrm{mg}$ per oyster, but also during the growth rebound from 1.2 to $1.6 \mathrm{~g}$.

Fig.6. Relationship between food availability (estimated by Chlorophyll a -RAZLEC database) carbohydrate storage, glycogen synthesis and growth. Arrows indicate the summer mortality period.

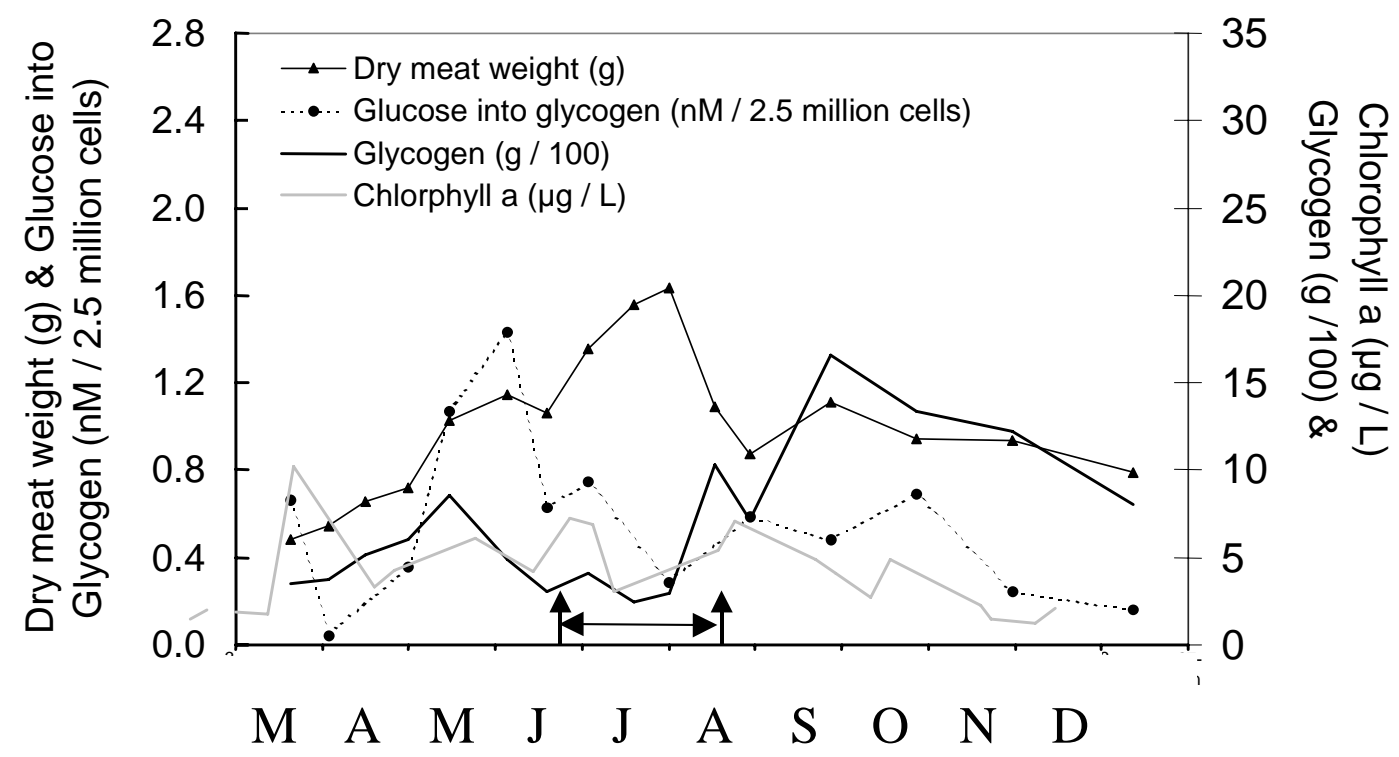

Our results reveal a specific succession of events : (1) disorder in carbohydrate metabolism and disruption in maturation process, preceding (2) the mortality event which occurred precisely during growth renewal and before spawning.

Since the estimated food availability (chlorophyll a) has not changed drastically during the study, other hypothesis to explain this disorder might concern either an increase in energetic demands during the intensive vitellogenesis process, or/and a change in phytoplankton quality which may further affect the primary trophic levels, and energetic conversion. Actually, food resources have recently shown a 'time delay' pattern with algal blooms occurring in Marennes-Oléron bay from March to October, while phytoplankton availability was previously more regularly centred in May (Soletchnik, 2001). A delay of algal blooming in Marennes-Oléron bay was 
reported, which can lead to food deficiency in the critical period in May. At that time, carrying capacity must sustain the high energetic cost of oyster maturation processes.

Further studies should examine energetic deficiency during the intense oyster vitellogenesis of oysters in Marennes-Oléron bay. Those studies should investigate any metabolism disorder during the maturation process in relation to changes in food supply quality (e.g., algal quality), which can be considered as an indicator of global environmental change. Those results will be used as a basis for further studies within the national research program MOREST, particularly in a controlled environement the laboratory level.

Frequent environmental changes in May - June during maturation process may cause oysters to adapt their metabolism from glycogen catabolism to glycogen synthesis. Those changes are likely energetically costly for oysters. Further investigation must be conducted to understand (1) how stress can effect the metabolic pathways to induce oyster mortality and (2) the physiological processes involved in the glycogen metabolism, including enzymatic activity patterns. While the experimental oyster batches originated from wild populations and both groups showed similar sensitivity rates to mortality events, it should be noted that recent genetic studies have provided selected strains tolerant to mortality rates (MOREST program) (Degremont et al., 2003; Boudry et al., 2004). Using those strains to develop comparative physiological studies would likely facilitate the understanding of the processes involved in abnormal mortality events as well as establishing relationship between genetics and physiological responses.

\section{Acknowledgements}

We would like to thank $\operatorname{Dr} \mathrm{H}$. MacCombie for facilitating the review and translation of this publication and the "LERPC" team for technical support of this study. 


\section{References}

Allen, S.K., Jr., Downing, S.L., 1986. Performance of triploid Pacific oysters, Crassostrea gigas (Thunberg). 1. Survival, growth, glycogen content, and sexual maturation in yearlings. J. Exp. Mar. Biol. Ecol. 102, 197-208.

Bayne, B.L., 1976. Marine mussels: their ecology and physiology. B. L. Bayne eds. Cambridge University Press Publisher. Australia. 506 p.

Beattie, J.H., Chew, K.K., Hershberger, W.K., 1980. Differential survival of selected strains of Pacific oysters $\underline{C}$. gigas during summer mortality. Proc. Nat. Shellfish Assoc. 70, 119-125.

Berthelin, C., Kellner, K., Mathieu, M., 2000a. Storage metabolism in the Pacific oyster (Crassostrea gigas) in relation to summer mortalities and reproductive cycle (west coast of France). Comp. Biochem. Physiol. 125, 359-369.

Berthelin, C., Kellner, K., Mathieu, M., 2000b. Histological characterization and glucose incorporation into glycogen of the Pacific oyster Crassostrea gigas storage cells. Mar. Biotechnol. 2, 136-145.

Bligh, E.G. and Dyer, W.F., 1959. A rapid method of total lipid extraction and purification. Can. J. Biochem. Physiol., 37 911-917.

Boudry, P., Degremont, L., Bédier, E., Samain, J.F., 2004. Selective breeding to improve resistance against summer mortality in the Pacific oyster Crassostrea gigas: results after 3 generations. J. Shellfish Res. 23, 281-282.

Cheney, D.P., Macdonald, B.F., Elston, R.A., 2000. Summer mortality of Pacific oyster, Crassostrea gigas (Thunberg): initial findings on multiple environmental stressors in Puget Sound, Washington, 1998. J. Shellfish Res. 19, 353-359.

Degremont, L., Boudry, P., Soletchnik, P., Bedier, E., Ropert, M., Huvet, A., Moal, J., Samain, J. F., 2003. Genetic basis of summer mortality in juvenile cupped oysters. J. Shellfish Res., 22, 1 :327.

Deslous-Paoli, J.M., Héral, M., 1988. Biochemical composition and energy value of Crassostrea gigas (Thunberg) cultured in the bay of Marennes-Oléron. Aquat. Living. Resour. 1, 239-249.

Dubois, M., Gilles, K.A., Hamilton, J.K., Rebers, P.A., Smith, F., 1956. Colorimetric method for determination of sugars and related substances. Anal. Chem. 28, 350-356.

Fando, J.J.L., Gacia-Fernandez, M.C., Candela, J.L.R., 1972. Glycogen metabolism in Ostrea edulis (L.) factors affecting glycogen synthesis. Comp. Biochem. Physiol., 807-814.

FAO, 2004. Annuaire de statistiques des Pêches 2002. Production de l'Aquaculture. Vol. 94/2. Statistiques $\mathrm{N}^{\circ} 181$ et Pêches N67. Rome, 206p.

Farley, C.G., 1992. Mass mortalities and infectious lethal diseases in bivalve molluscs and association with geographic transfers of populations. In: Rosenfield, A., Mann, R. (Eds), Dispersal of living organisms into aquatic ecosystems. Maryland Sea Grant Publishers, College Park, Maryland, pp. 139155.

Gabbott, P.A., 1975. Storage cycles in marine bivalve molluscs: A hypothesis concerning the relationship between glycogen metabolism and gametogenesis. In: Scotland Aberdeen University Press (Eds.), Proceedings of the $9^{\text {th }}$ Europ. Mar. Biol. Symposium, Aberdeen, UK, pp 191-211. 
Gabbott, P.A., 1983. Developmental and seasonal metabolic activities in marine molluscs. In : Hochachka, P.W., (Eds.), The Mollusca, Vol. 2, Environmental biochemistry and physiology, pp 165-217.

Gabbott, P.A., Whittle, M.A., 1986. Glycogen synthetase in the sea mussel Mytilus edulis L. II. Seasonal changes in glycogen content and glycogen synthetase activity in the mantle tissue. Comp. Biochem. Physiol. 83B, 197-207.

Galtsoff P.S., 1964. The American oyster, Crassostrea virginica (G). Fish Bull. US 64, 1-480.

Glude, J.B., 1975. A summary report of Pacific coast oyster mortality investigations (1965-1972). Proceedings of the 3rd US Japan meeting on aquaculture at Tokyo, Japan. October 1974, 29-34.

Goulletquer P. and M. Héral, 1997. History, present conditions and future of the Molluscan fisheries of North America and Europe. Marine Molluscan production trends in France: from fisheries to aquaculture. Marine Fisheries Review, NOAA Technical Report NMFS, 129:137-164.

Goulletquer, P., Soletchnik, P., Le Moine, O., Razet, D., Geairon, P., Faury, N., Taillade, S., 1998. Summer mortality of the cupped oyster Crassostrea gigas in the bay of Marennes Oléron (France). ICES, Lisbon, CM. CC/14, pp 14-20.

Grizel, H., 1996. Quelques exemples d'introductions et de transferts de mollusques. Revue Scientifique et Technique de l'Office International des Epizooties 15, 401-408.

Héral, M., Deslous-Paoli, J.M., Sornin, J.M., 1983. Transferts énergétiques entre

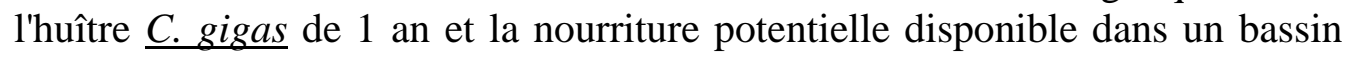
ostréicole: premières approches. Océanis 9, 169-194.

Heude-Berthelin, C., 2000. Study of glycogen metabolism in the oyster Crassostrea gigas: consequences on reproduction and summer mortalities. $\mathrm{PhD}$ thesis, Caen Univ., France, pp156.

Heude-Berthelin, C., Laisney, J., Espinosa, J., Martin, O., Hernandez, G., Mathieu, M., 2001. Storage and reproductive strategy in Crassostrea gigas from two different growing areas (Normandy and the Atlantic coast, France). Invertebr. Reprod. Dev., 40, 1:79-86.

Imai, T., Numachi, K., Oizumi, J., Sato, S., 1965. Studies on the mass mortality of the oyster in Matsushima Bay. II Search for the cause of mass mortality and the possibility to prevent it by transplantation experiment. Bull. Tohoku Reg. Fish Res. Lab. 25, 27-38.

Koganazawa, A., 1975. Present status of studies on the mass mortality of cultural oysters in Japan and its prevention, Proceedings of the Third U.S.-Japan Meeting on Aquaculture, Tokyo, Japan, pp 29-34.

Lenoir, F., Robbins, I., Mathieu, M., Lubet, P., Babbott, P.A., 1989. Isolation, characterization and glucose metabolism of glycogen cells (= vesicular connective-tissue cells) from the labial palps of the marine mussel Mytilus edulis. Mar. Biol. 101, 495-501.

Lodato, M.I., 1997. Spring mortality of Crassostrea gigas in the oyster reefs at Perquis and Ronce (France, Bay of Marennes-Oleron): Study of oyster rearing methodologies and biological and spatial characteristics. PhD. Ecole Natl. Vétérinaire, Nantes, France, pp127.

Mackin, J.G., 1961. Mortalities of oysters. Proc. Nat. Shellfish Ass. 50, 40-51.

Mann, R., 1979. Some biochemical and physiological aspects of growth and gametogenesis on Crassostrea gigas and Ostrea edulis grown at sustained elevated temperatures. J. Mar. Biol. Ass. U.K. 59, 95110. 
Marsh, J.B., Weinstein, D.B., 1966. Simple charring method for determination of lipids. J. Lipid Res. 7, 574-576.

Mathieu, M., Lubet, P., 1993. Storage tissue metabolism and reproduction in marine bivalves -a brief review. Inv. Reprod. Dev. 23, 123-129.

Maurer D., Borel, M., 1986. Croissance, engraissement et cycle sexuel de Crassostrea gigas dans le Bassin d'Arcachon : comparaison des huîtres agées de 1 et 2 ans. Haliotis 15, 125-134.

Maurer, D., Comps, M., His, E., 1986. Caractéristiques des mortalités printanières de l'huître Crassostrea gigas dans le Bassin d'Arcachon. Haliotis 15, 309-317.

Mori, K., Tamate, H., Imai, T., Itikawa, O., 1965. Changes in the metabolism of lipids and glycogen of the oyster during the stages of sexual maturation and spawning. Bull. Tohoku Reg. Fish. Res. Lab. 25, 65-88.

Mori, K., 1979. Effects of artificial eutrophication on the metabolism of the Japanese oyster C. gigas. Mar. Biol. 53, 361-369.

Parache, A., 1989. Growth performance of oyster Crassostrea angulata and Crassostrea gigas reared in Arcachon Bay between 1950 and 1986: first results. Haliotis 19, 227-236.

Perdue, J.A., Beattie, J.H., Chew, K.K., 1981. Some relationship between gametogenic cycle and summer mortality phenomenon in the Pacific oyster (Crassostrea gigas) in Washington State. J. Shellfish. Res. 1, 9-16.

Perdue, J.A., 1983. The relationship between the gametogenic cycle of the Pacific oyster $\underline{C}$. gigas and the summer mortality phenomenon in strains of selectively bred oysters. PhD dissertation, University of Washington, pp. 205.

Renault, T., Le Deuff, R.L., Cochennec, N., Chollet, B., Maffart, P., 1995. Herpeslike viruses associated with high mortality levels in larvae and spat of Pacific oysters, Crassostrea gigas: a comparative study, the thermal effects on virus detection, in hatchery reared larvae, reproduction of the disease in axenic larvae. Vet. Res. 26, 539-543.

Ruiz, C., Abad, M., Sedano, F., Garcia-Martin, L.O., Sanchez Lopez, J.L., 1992. Influence of seasonal environmental changes on the gamete production and biochemical composition of Crassostrea gigas (Thunberg) in suspended culture in El Grove, Galicia, Spain. J. Exp. Mar. Biol. Ecol. 155, 249-262.

Sinderman, C.J., 1976. Oyster mortalities and their control. In: Pillay, T.V.R., Dill, W.M., (Eds.), Advances in Aquaculture, Fishing News Brooks Farnham Publishers, England, pp. 349-361.

Soletchnik, P., Faury, N., Razet, D., Goulletquer, P., 1998. Hydrobiology of the Marennes-Oléron Bay: seasonal indices and analysis of trends from 1978 to 1995. Hydrobiologia 386, 131-146.

Soletchnik, P., Le Moine, O., Faury, N., Razet, D., Geairon, P., Goulletquer, P., 1999. Mortalité de l'huître Crassostrea gigas dans le Bassin de Marennes Oléron. Etude de la variabilité spatiale de son environnement et de sa biologie par un système d'information géographique (SIG). Aquat. Living. Resour. 12, 131-143.

Soletchnik, P., 2001. Impact of the climatic change on an estuarian ecosystem : the Marennes Oléron Bay. French IGBP-WCRP news letter 12, 37-41.

Soletchnik P., Lambert, C., Costil, K., 2005. Summer mortality of Crassostrea gigas (Thunberg) in relation to environmental rearing conditions. J. Shellfish Res. 24, 197-207. 
Tamate, H., Numachi, K.I., Mori, K., Itikawa O., Imai, T., 1965. Studies on the Mass Mortality of the Oyster in Matsushima Bay VI. Pathological Studies. Bull. Tohoku Reg. Fish. Res. Lab. 25, 89-104.

Walne, P.R., Mann R., 1975. Growth and biochemical composition in Ostrea edulis and C. gigas. Proc. $9^{\text {th }}$ EMBS Aberdeen, H. Barnes Ed., 587-607. 